\title{
The Amplitude of Scientific Medical Microbiology
}

\author{
Adenilda Cristina Honorio-Franca* \\ Institute of Biological and Health Science, Federal University of Mato Grosso, Barra do Garcas, MT-Brazil
}

In this issue of the Journal \& Medical Microbiology \& Diagnosis brings the public a journal of quality assessments continually attested by pairs, which ensures the maintenance of the principles seriousness and scientific academic excellence that already constitute a property of publication and extension the community of researchers in the area of medical microbiology.

That is why the editorial activities which must be understood as a result of an effort to maintain the high level of articles. It is important to inform collaborators of Journal of Medical Microbiology \& Diagnosis - be the authors of articles published or reviewers - that editors brings as a result a Journal that has published articles of high importance and merit which make up an extremely rich panel of scientific researchers in the areas of Molecular Mechanisms of Viruses, Genetics of Pathogens, Immunology, Epidemiology Bacterial Pathogenecity and Immune Response.

On the other hand, Gastrointestinal Infections are commonly associated to specific pathogens. Acute diarrhea is the second main cause of death in low socio-economic level infants in developing countries. Enterotoxigenic Escherichia coli (ETEC) and enteropathogenic Escherichia coli (EPEC) are important causative agents of death from diarrhea. ETEC is the main cause of diarrhea in developing countries and accounts for 800 million deaths a year, affecting especially children under the age of five years. Another important pathogen that attacks infants is the bacterium Streptococcus pneumonia mostly associated with acute otitis media and S. pneumoniae is the second most common cause of meningitis in children under 2 years of age.

The process of confrontation of bacterial infections and endemic diseases are becoming a significant challenge. The global context and social demands participation of the scientific community with a new position as a forming agent. Thus, Journal of Medical Microbiology \& Diagnosis is a means of dissemination of scientific and starts a new stage in medical microbiology with the publication that represents the beginning of this new era of microbiology with a growing process of scientific growth with the expectation that the community microbiology collaborate in scientific advancement. We want to partner with all researchers and also we seek to share this growth with all groups that produce quality science in the world.

Thus, different approaches each with a central concern may contribute to the advancement of the academic world and the continuous improvement of knowledge of techniques and methods of treatment especially of bacterial infections. In relation to scientific knowledge more studies and research results were put into circulation accessible to the public contributing to advance in the understand of medical importance of microorganisms, as bacteria, and their capability of causing diseases in human.

We invite all researchers to enjoy this journal with a critical sight, but also with a look of welcome we can add opinions and suggestions for the advancement of knowledge in medical microbiology.

\footnotetext{
*Corresponding author: Adenilda Cristina Honorio-Franca, Professor of Institute of Biological and Health Science, Federal University of Mato Grosso, Barra do Garcas, MT- Brazil, Tel: 66-34021121; E-mail: adenilda@cpd.ufmt.br

Received November 22, 2011; Accepted December 22, 2011; Published December 26, 2011

Citation: Honorio-Franca AC (2012) The Amplitude of Scientific Medical Microbiology. J Medical Microbiol Diagnosis 1:e102. doi:10.4172/2161-0703.1000e102

Copyright: (c) 2012 Honorio-Franca AC. This is an open-access article distributed under the terms of the Creative Commons Attribution License, which permits unrestricted use, distribution, and reproduction in any medium, provided the original author and source are credited.
} 